Accepted for publication in Journal of Applied Polymer Science Published in 2020

DOI: 10.1002/app.49999 


\title{
Evaluating the cell structure-impact damping relation of cross-linked polyethylene foams by falling weight impact tests
}

\author{
Márton Tomin ${ }^{\mathrm{a}}$ Ákos Kmettya, b \\ ${ }^{a}$ Department of Polymer Engineering, Faculty of Mechanical Engineering, Budapest University of \\ Technology and Economics, H-1111 Budapest, Múegyetem rkp. 3, Hungary \\ ${ }^{b}$ MTA-BME Research Group for Composite Science and Technology, H-1111 Budapest, Múegyetem rkp. \\ 3., Hungary \\ Correspondence to: Ákos Kmetty (E-mail: kmetty@pt.bme.hu)
}

\begin{abstract}
This study examines the effect of foam thickness on impact damping properties of closed-cell cross-linked polyethylene foams of different densities. Compression tests and falling weight impact tests were performed to detect the most important mechanisms which affect the mechanical properties of the foams. The results showed that impact damping properties are significantly influenced by foam thickness, while energy-absorbing capability primarily depends on foam density. The average cell diameter was determined with a scanning electron microscope, which proved that the mechanical properties are mostly influenced by cell structure because higher density foams have smaller cells and thicker cell walls. Other important conclusion is that a foam thickness limit can be determined for a given load level to avoid excessive compaction of the cells and maximize the shock absorption of the foam.
\end{abstract}

\section{INTRODUCTION}

Polymer foams are two-phase materials that contain statistically dispersed gas bubbles of different sizes in a polymer matrix ${ }^{1}$. This special structure has a number of advantageous properties, the most important of which is low density, as the importance of weight reduction is constantly increasing in all industries due to the environmental regulations of recent years ${ }^{2,3}$. Other important advantages of polymer foams are excellent thermal ${ }^{4}$ and sound insulation ${ }^{5}$, as well as the outstanding energy absorption and impact damping properties ${ }^{6}$. This is exploited, for example, in the automotive industry, where the instrument panel and side panels often contain a layer of polymer foam, which is designed to protect occupants in the event of collisions and accidents ${ }^{7}$. Another important segment is the packaging industry, where packaging materials with adequate impact damping capability are essential to prevent the product being damaged during transport ${ }^{8}$.

In addition to the industries listed above, the impact damping capability of foams is also exploited by the sports equipment industry, where polymer foams are used in both sportswear and sports mats. For example, shoe soles made of polymer foam reduce the load on the knee joint of runners ${ }^{9,10}$, while protective clothing in motorsports can save lives. In addition, sports mats produced from polymer foams are used in martial arts, jumping, and gymnastics, as the load on the athlete at the moment of landing must be reduced to prevent sports injuries ${ }^{11}$. 
The most commonly used test method for assessing the impact damping capability of polymeric foam products is the so-called falling weight impact test, in which a body of a given mass and geometry is dropped from a given height onto a test specimen. From the force or deceleration measured during the impact, the energy absorbing and impact damping capability of the product can be determined ${ }^{12}$. In previous research, two types of test arrangements have been used, which mainly differ in the type of the applied support: support with a hole, where the sample is perforated by the striker ${ }^{13}$, and solid support, where the weight rebounds from the sample ${ }^{14}$. In the sporting goods industry and packaging industry, the solid support test gives more relevant results because the loads on the foam simulate the real-life use of the products better.

The results of this type of falling weight impact test is summarized in the so-called cushion curve used by design engineers in the packaging industry ${ }^{15}$. The grading of sports mats based on such tests is required by various sport-specific standards ${ }^{16-18}$. However, it is important to emphasize that the requirements for each sport are different in terms of applicable impact energy, drop height, and falling weight mass, so it is difficult to compare the properties of products for different applications ${ }^{16-18}$. In addition to the various test parameters, the geometry of the falling weight, which gets into contact with the tested foam, also greatly influences the test results. This was demonstrated by Flores-Johnson and $\mathrm{Li}^{19}$, who performed dynamic mechanical tests using six different impactor shapes on closed-cell polymethacrylimide foams with densities of $52 \mathrm{~kg} / \mathrm{m}^{3}$ and $110 \mathrm{~kg} / \mathrm{m}^{3}$. A similar conclusion was reached by Mills and Gilchrist ${ }^{20}$, who showed by investigating bicycle and motorcycle helmets that different foam structures provide complete protection for collisions with objects of different geometries.

There are also several studies on the dynamic mechanical investigation of polymer foams, which primarily focus on the study of the effect of air between foam cells and foam density. Lopez Gonzalez et al. ${ }^{21}$ studied the effect of open-cell content on same density low density polyethylene and ethylene-vinyl acetate foams and showed that at high deformation rates, an open-cell foam with high tortuosity approaches the properties of closed-cell foams, wherein the compression of gas in the cells improves the shock-absorbing capability of the foam. (Tortuosity gives the required distance which a gas molecule has to move to get from one side of the foam to the other). Similarly, Mills and Lyn ${ }^{22}$ related the air permeability of rebonded polyurethane foams to their shock-absorbing properties.

In addition, some research has reported promising results that better energy absorption can be achieved with functionally graded foams which have non-uniform density distribution along the thickness. These foams can exhibit higher energy absorption compared to equivalent uniform foams ${ }^{23-25}$. However, in order to determine the optimal foam thickness and density distribution, we have to know the exact effect of the two characteristics on dynamic mechanical properties, but none of the studies reported conclusive results in this topic.

Several publications discussed the comparison of different density foams. Juntunen et al. ${ }^{26}$ performed falling weight impact tests on microcellular polyvinyl-chloride foams with a relative density of 0.6 to 1.0 in accordance with the ASTM D4226 standard. The results showed a linear relationship between relative density and impact strength. In contrast, our previous study ${ }^{27}$ on cross-linked polyethylene foams showed that the relationship between foam density and mechanical properties could be described by the power 
law. Marsavina et al. ${ }^{28}$ also showed that mechanical properties are primarily influenced by the density of the foam, which has a more significant effect than the direction of the load. They used static three-point bending and dynamic impact tests on $40-160 \mathrm{~kg} / \mathrm{m}^{3}$ density closed-cell, rigid polyurethane foams.

Foam thickness is also extremely important, but few studies have investigated its effect. Although Lyn and Mills ${ }^{29}$ studied rebonded polyurethane foams in different thicknesses, the densities of the samples were different, making it difficult to draw conclusions about the effect of thickness.

As the effect of foam thickness is not fully explored, the aim of our research is to study the relationship between the thickness and impact damping properties of polymer foams.

We investigated cross-linked polyethylene foams (XPE) of various densities. XPE foams are among the most popular foam types in both the sports goods industry and the packaging industry, as they have higher heat resistance, and can recover better after mechanical loads due to their weakly cross-linked structure ${ }^{30}$. Since polymer foams are widely used as the core material in various metal-polymer hybrid sandwich structures ${ }^{31}$, the results of our research can be used in many segments of the industry in addition to the applications mentioned above. 


\section{EXPERIMENTAL}

\section{Materials}

Cross-linked polyethylene foams supplied by Polifoam Ltd. (Budapest, Hungary) in the density range of $30-70 \mathrm{~kg} / \mathrm{m}^{3}$ and in the thickness range of $10-60 \mathrm{~mm}$ were tested in order to analyze the effect of thickness and density on impact damping and energy-absorbing properties. The foams were produced on a flat sheet production line with the use of azodicarbonamide as foaming agent and dicumyl peroxide crosslinking agent. TABLE 1 shows the notation, theoretical density, real density, and thickness of the tested samples. The real density of the samples was calculated from their volume and mass.

TABLE 1 Main properties of the investigated samples

\begin{tabular}{|l|c|c|c|}
\hline Sample & $\begin{array}{c}\text { Theoretical density } \\
{\left[\mathrm{kg} / \mathrm{m}^{3}\right]}\end{array}$ & $\begin{array}{c}\text { Real density } \\
{\left[\mathrm{kg} / \mathrm{m}^{3}\right]}\end{array}$ & $\begin{array}{c}\text { Thickness } \\
{[\mathrm{mm}]}\end{array}$ \\
\hline C3010 & 30 & $28.0 \pm 0.2$ & 10 \\
\hline C3020 & 30 & $27.8 \pm 0.5$ & 20 \\
\hline C3030 & 30 & $29.5 \pm 0.1$ & 30 \\
\hline C3040 & 30 & $28.6 \pm 0.6$ & 40 \\
\hline C3050 & 30 & $27.6 \pm 0.5$ & 50 \\
\hline C3060 & 30 & $28.8 \pm 0.3$ & 60 \\
\hline C4010 & 40 & $48.3 \pm 3.0$ & 10 \\
\hline C4020 & 40 & $41.9 \pm 1.3$ & 20 \\
\hline C4030 & 40 & $41.1 \pm 2.0$ & 30 \\
\hline C4040 & 40 & $43.4 \pm 0.4$ & 40 \\
\hline C4050 & 40 & $45.7 \pm 1.1$ & 50 \\
\hline C4060 & 40 & $39.7 \pm 0.2$ & 60 \\
\hline C5010 & 50 & $47.3 \pm 0.8$ & 10 \\
\hline C5020 & 50 & $47.0 \pm 0.5$ & 20 \\
\hline C5030 & 50 & $47.7 \pm 1.1$ & 30 \\
\hline C5040 & 50 & $45.3 \pm 0.5$ & 40 \\
\hline C5050 & 50 & $45.9 \pm 0.8$ & 50 \\
\hline C5060 & 50 & $50.1 \pm 0.2$ & 60 \\
\hline C7010 & 70 & $67.2 \pm 1.8$ & 10 \\
\hline C7020 & 70 & $68.8 \pm 0.7$ & 20 \\
\hline C7030 & 70 & $68.7 \pm 0.6$ & 30 \\
\hline C7040 & $70.1 \pm 1.3$ & 40 \\
\hline C7050 & 70 & $73.8 \pm 0.9$ & 60 \\
\hline C7060 & & & \\
\hline
\end{tabular}

The samples with a thickness of more than $10 \mathrm{~mm}$ were welded together from several $10 \mathrm{~mm}$ thick layers by flame lamination. Flame lamination is a fast and cost-effective technology, in which pre-fabricated foamed sheets are passed through an open flame with rollers, but only for the time necessary to form a 
thin, liquid polymer layer on the surface of the foamed sheet and then pressed the sheets together. The quality of welding depends on gas type, flame height, and flame spread rate. This technology is widely used for multilayer sanitary and sports mattresses, as strict medical regulations generally do not allow the use of an adhesive ${ }^{32}$.

\section{Methods}

\section{Scanning electron microscopy}

The cell structures of different density samples were examined with a JEOL JSM 6380LA (Tokyo, Japan) scanning electron microscope (SEM). We prepared the foam specimens by immersing them in liquid nitrogen to create cryogenic fracture surfaces, and then coated them with a gold-palladium alloy to ensure adequate conductivity. With the help of the SEM images, cell structure, the welding interlayer formed by flame lamination, and the effect of falling weight impact tests on the foam structure were examined.

Using the electron microscope images and the density of the samples, we determined their relative densities (1) and the extent of expansion (2). Then we calculated cell density (3), cell nucleation (4), and average cell wall thickness (5) ${ }^{33}$.

$$
\begin{gathered}
\rho_{\text {rel }}=\frac{\rho_{\text {foam }}}{\rho_{\text {solid }}}[-] \\
\phi=\frac{1}{\rho_{\text {rel }}}[-] \\
N_{C}=\left(\frac{n}{A}\right)^{\frac{3}{2}}\left[\frac{\mathrm{cells}}{\mathrm{cm}^{3}}\right] \\
N=N_{C} \cdot \phi\left[\frac{\mathrm{cells}}{\mathrm{cm}^{3}}\right] \\
\delta=\left(\sqrt[3]{\frac{\phi}{\phi-1}}-1\right) \cdot l[\mu \mathrm{m}]
\end{gathered}
$$

where $\rho_{\text {rel }}[-]$ is the relative density, $\rho_{\text {foam }}\left[\mathrm{kg} / \mathrm{m}^{3}\right]$ is the measured density of the foam sample, $\rho_{\text {solid }}=915$ $\left[\mathrm{kg} / \mathrm{m}^{3}\right]$ is the density of the solid material before foaming, $\phi[-]$ is the extent of expansion, $N_{c}\left[\mathrm{cells} / \mathrm{cm}^{3}\right]$ is the cell density, $n$ [cells] is the number of the cells in the SEM image, $A\left[\mathrm{~cm}^{2}\right]$ is the investigated area of the sample, $N$ [cells $\left./ \mathrm{cm}^{3}\right]$ is the cell nucleation, $\delta[\mu \mathrm{m}]$ is the average cell wall thickness, and $l[\mu \mathrm{m}]$ is the average size of the cells. Cell density shows the number of the cells in a given volume cube, which was determined from the number of cells detected in the same area of the SEM image as the side of the cube.

To calculate cell wall thickness, we needed the average size of cells (6), which was determined in two different ways: from SEM images, using image analysis software, and based on Chul ${ }^{34}$ assuming a homogeneous cell structure, considering the cells as regular cubes (FIGURE 1) using the following formula:

$$
l=\sqrt[3]{\frac{\phi-1}{N}} \cdot 10^{4}[\mu m]
$$


The characteristics determined by the image analysis software are hereinafter marked with the index " $m$ ".

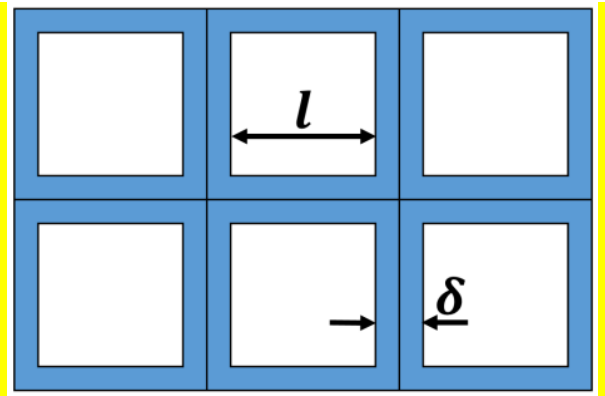

FIGURE 1 Cross section of the assumed cell structure (based on Chul) ${ }^{34}$

\section{Compression tests}

The compression tests were performed at room temperature with a Zwick Z020 (Ulm, Germany) testing machine equipped with a Gassmann Theiss Messtechnik (Bickenbach, Germany) load cell (measuring range $0-20 \mathrm{kN}$ ). Test speed was $20 \mathrm{~mm} / \mathrm{min}$ and all the specimens were compressed to $5 \%$ of their original thickness. We cut $100 \mathrm{~mm} \times 100 \mathrm{~mm}$ samples from foam samples C3010, C4010, C5010 and C7010, and calculated the compression deflection (CD) of the foams according to the ASTM D3575 standard:

$$
C D=\frac{10^{3} \cdot F_{25}}{S}[k P a]
$$

where $F_{25}[\mathrm{~N}]$ is the force at $25 \%$ deformation, while $S\left[\mathrm{~mm}^{2}\right]$ is the contact surface area of the specimen during compression.

\section{Falling weight impact tests}

For the dynamic mechanical tests two different devices were used: a Ceast 9350 (Turin, Italy) falling weight impact tester ("type A"), and a falling weight test device that we designed ("type B"), to check compliance with the requirements of the United World Wrestling (UWW) for wrestling mats. By using two different test methods, we get a more comprehensive picture of the response of polymer foams to dynamic mechanical loading, and we can compare the results obtained with different test parameters. In the case of "type A" tests, the original test layout was modified, and the support with the hole was replaced with a $40 \mathrm{~mm}$ thick solid metal support, which made it possible to create an arrangement that better models the real-life use of polymeric foam products. For the tests we prepared 10 samples of $100 \mathrm{~mm} \times 100 \mathrm{~mm}$ size from each foam, (thickness and material type can be found in TABLE 1).

"Type B" measurements were performed in accordance with the MSZ-20333-2015 standard. For these tests, 3 samples of $200 \mathrm{~mm} \times 200 \mathrm{~mm}$ size were prepared for each foam type, and each sample was subjected to 8 drops. The main objectives of the tests were to investigate the applicability of the foam samples as sports mats and to analyze the effect of repetitive impact on impact damping properties. The time interval between the drops was one minute.

The impact energy and falling weight geometry used in the two types of tests were different (TABLE 2). 
TABLE 2 Test parameters for the falling weight impact tests

\begin{tabular}{|c|c|c|}
\hline Property & "Type A" & "Type B" \\
\hline Falling weight geometry & Cylinder & Cylinder \\
\hline Falling weight diameter & $50 \mathrm{~mm}$ & $100 \mathrm{~mm}$ \\
\hline Falling weight mass & $5,604 \mathrm{~kg}$ & $10,025 \mathrm{~kg}$ \\
\hline Drop height & $400 \mathrm{~mm}$ & $400 \mathrm{~mm}$ \\
\hline Impact energy & $21.98 \mathrm{~J}$ & $39.3 \mathrm{~J}$ \\
\hline Test temperature & $23^{\circ} \mathrm{C}$ & $23^{\circ} \mathrm{C}$ \\
\hline
\end{tabular}

In the evaluation of the results, we focused on the following four mechanical parameters: energy absorbed during impact $-E[\%]$, maximum force on the weight $-F[k N]$, maximum deformation of the foam - $\mathrm{p}[\mathrm{mm}]$, and duration of the impact $-\mathrm{t}[\mathrm{ms}]$.

\section{RESULTS AND DISCUSSION}

\section{Scanning electron microscopy}

The SEM images of the different density foams (FIGURE 2) show that the foams have a closed cell structure, as the cells are completely separated from each other by the cell walls, so free air flow between the cells is not possible.

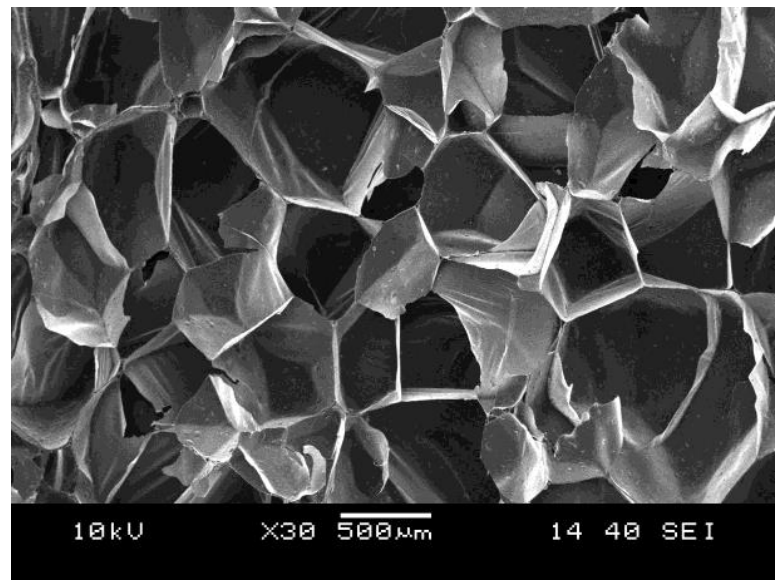

(a)

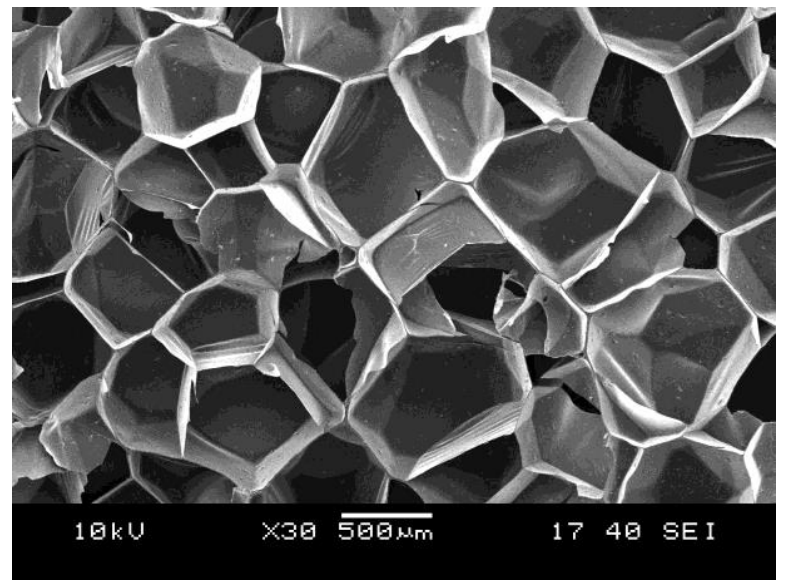

(b) 


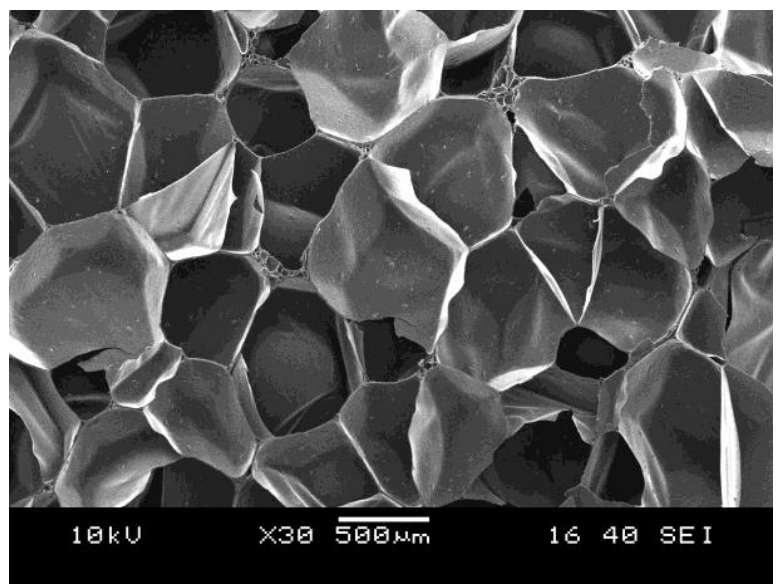

(c)

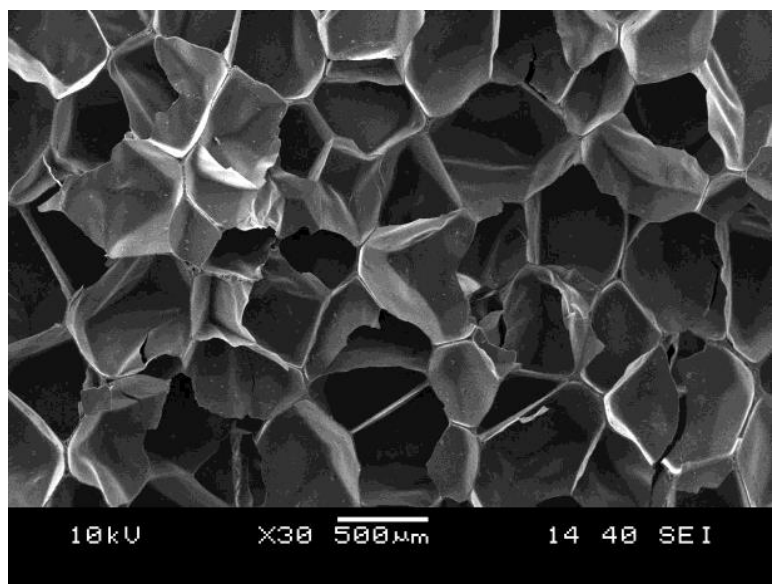

(d)

FIGURE 2 SEM images of different density XPE foams a) $30 \mathrm{~kg} / \mathrm{m}^{3}$, (b) $40 \mathrm{~kg} / \mathrm{m}^{3}$, (c) $50 \mathrm{~kg} / \mathrm{m}^{3}$, (d) $70 \mathrm{~kg} / \mathrm{m}^{3}$

Average cell sizes were calculated with formula (6), which assumes homogeneous distribution. The calculated results were almost the same as average cell sizes determined with the image analysis software, when the deviation fields were taken into account. Thus, the cell structure of the investigated foams can be considered homogeneous and regular, which validates the applicability of formulas (3)-(5).

The data in TABLE 3 indicate that higher density foams have smaller cell sizes, and the difference in the average cell diameters of the different density foams is significant. This was confirmed by single-factor variance analysis (at a significance level of $95 \%$ ). The p-value of the analysis is three orders of magnitude smaller than 0.05 . From the cell density of the foams, which shows the number of cells in one $\mathrm{cm}^{3}$, it can be seen that as foam density increases, the structure contains more and more smaller cells. This, together with increasing cell wall thickness, results in a stiffer and more load-resistant structure, which fundamentally affects its mechanical properties.

TABLE 3 Cell structure characteristics of the tested foams

(" $\mathrm{m}$ " means the results which were determined by the image analysis software)

\begin{tabular}{|c|c|c|c|c|}
\hline Sample & C3030 & C4030 & C5030 & C7030 \\
\hline $\mathbf{N c}\left[\mathbf{c e l l s} / \mathbf{c m}^{3}\right.$ ] & 2815 & 4194 & 4839 & 6947 \\
\hline $\mathbf{N}\left[\mathbf{c e l l s} / \mathbf{c m}^{3}\right]$ & 88831 & 93599 & 92236 & 92129 \\
\hline$I_{\mathrm{m}}[\boldsymbol{\mu m}]$ & $622 \pm 151$ & $567 \pm 163$ & $500 \pm 138$ & $464 \pm 108$ \\
\hline$I_{[}[\boldsymbol{\mu m}]$ & 701 & 611 & 581 & 511 \\
\hline $\boldsymbol{\delta}_{\mathrm{m}}[\boldsymbol{\mu \mathrm { m }}]$ & 6,7 & 8,7 & 9,1 & 12,3 \\
\hline $\boldsymbol{\delta}[\boldsymbol{\mu m}]$ & 7,6 & 9,4 & 10,5 & 13,5 \\
\hline
\end{tabular}

With the help of the SEM images, we not only characterized cell structure, but also examined the interlayers formed during the welding of the $10 \mathrm{~mm}$ thick layers. FIGURE 3 shows the welding interlayers of the $30 \mathrm{~mm}$ thick samples of different densities (marked with red rectangles). An inhomogeneous interphase was formed between the foam sheets, whose thickness exceeds the thickness of the cell walls. 
It can be explained by the fact that during welding, the surface of the foam sheets got into contact with the flame, therefore in a thin layer, the cells collapsed and then welded together.

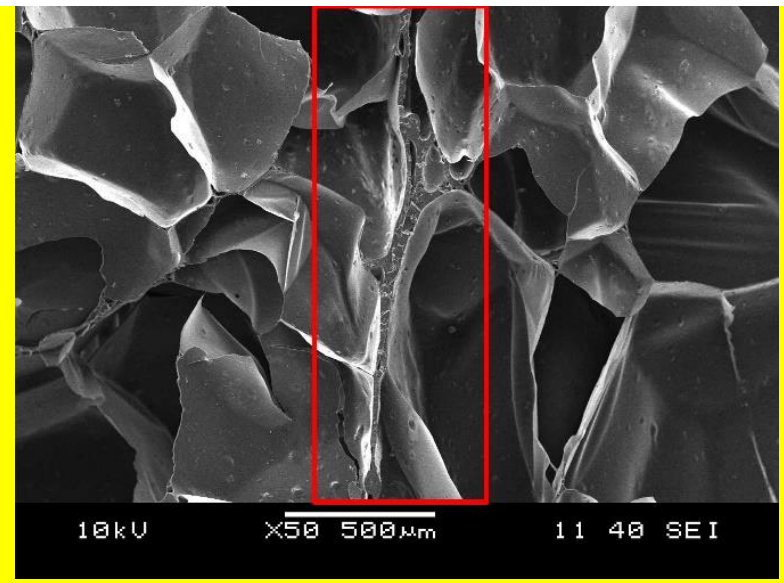

(a)

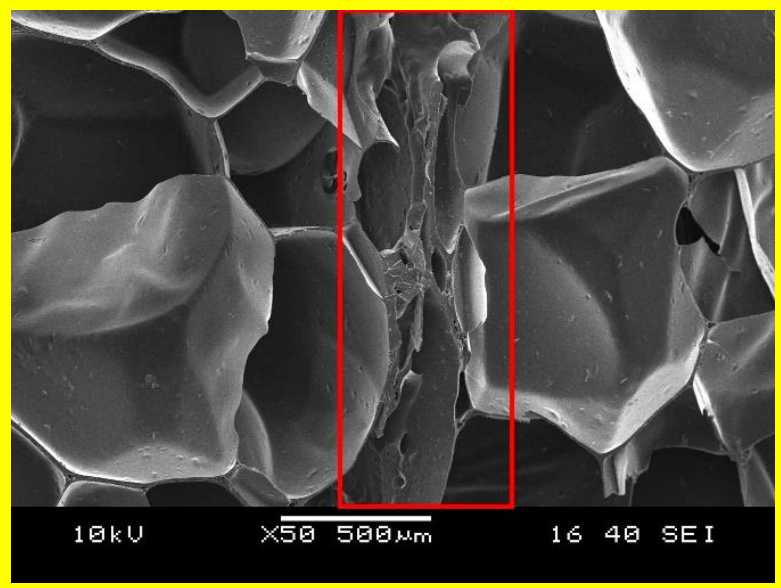

(c)

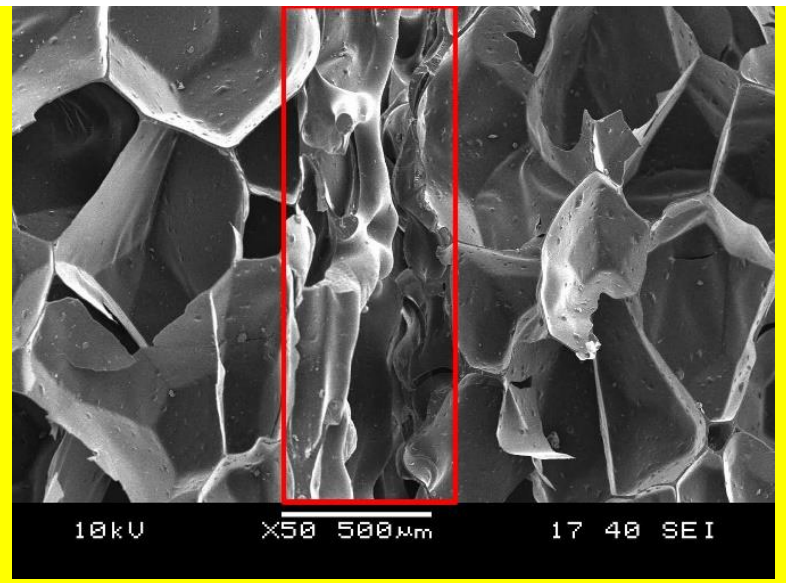

(b)

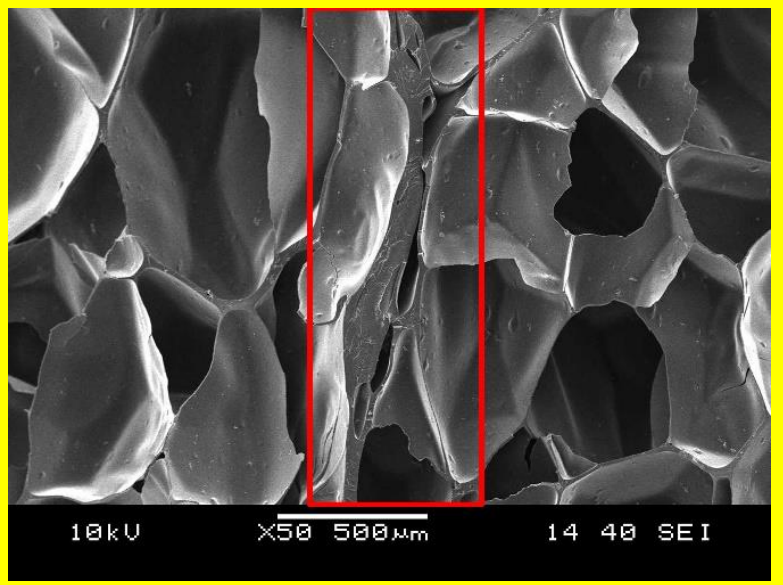

(d)

FIGURE 3 SEM images of the welded interlayer of different density samples (a) $30 \mathrm{~kg} / \mathrm{m}^{3}$, (b) $40 \mathrm{~kg} / \mathrm{m}^{3}$, (c) $50 \mathrm{~kg} / \mathrm{m}^{3}$, (d) $70 \mathrm{~kg} / \mathrm{m}^{3}$

\section{Compression tests}

During the compression tests, the force and displacement data were recorded, from which we determined the stress-strain curves of the foams (FIGURE 4). 


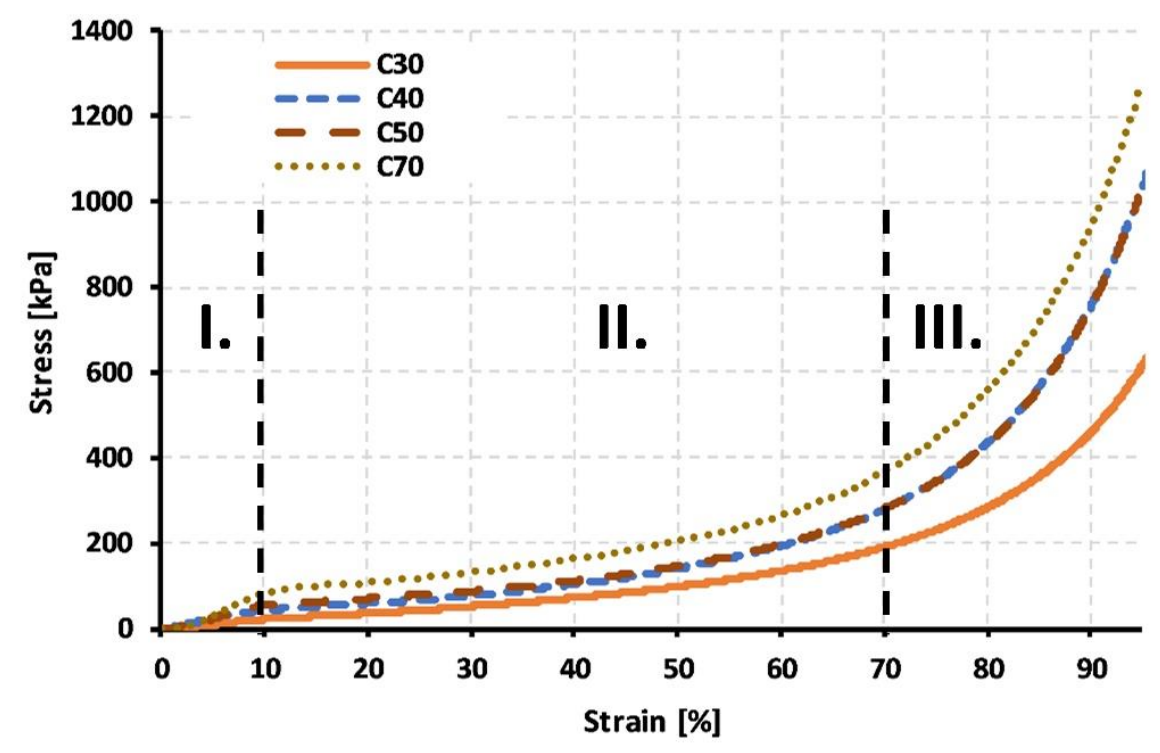

FIGURE 4 Stress-strain curves of the different density foams from compression tests

These can be divided into three different regions, which corresponds to the trend for closed-cell foams in the literature ${ }^{35}$. In the initial region (I.) of the curves (up to about $10 \%$ deformation) after the inflection point caused by pre-loading, the nature of deformation is almost linearly elastic; the slope of the curve gives the compressive Young's modulus of the foams. This is followed by the so-called stress plateau, where the stress increases only slightly. This region (II.) can be associated with the deformation of the foam cells; due to cell wall buckling and cell edge bending, the cells start to collapse. The last region (III.) is the so-called densification zone (above $70 \%$ strain). Here, stress increases suddenly because a further compression of the air between the cells leads to an increase in pressure, and finally the opposite cell walls get into contact as well.

It can be seen that the character of the curves is greatly influenced by the density of the foams, since in the case of denser foams, the rigid structure (several smaller cells, thicker cell walls) increased the initial slope of the curve and led to a higher Young's modulus and stress plateau. Due to the smaller cell diameter, the third region (compression of the air in the cells and the meeting of opposite cell walls) also starts at a smaller strain. The calculated compression deflection values, which characterize the plateau section of the curves also show a similar trend: they increase in proportion to density. C3010 samples showed $42.9 \pm 0.6 \mathrm{kPa}, \mathrm{C} 4010$ samples showed $66.5 \pm 1.4 \mathrm{kPa}, \mathrm{C} 5010$ samples showed $73.5 \pm 9.1 \mathrm{kPa}$, while C7010 samples showed $120.5 \pm 1.7 \mathrm{kPa}$ compression deflection. The smaller difference between the results of C4010 and C5010 foams is due to their nearly equal real densities.

\section{Falling weight impact tests}

In the case of the "type A" falling weight impact tests, the striker rebounded from the tested specimens in all cases due to the solid support, which did not cause any visible damage on the samples. During the tests, the force-time diagrams were recorded, from which we determined the maximum force on the 
weight, the maximum deformation of the foam, the duration of the impact, and the amount of energy absorbed during the impact (FIGURE 5).

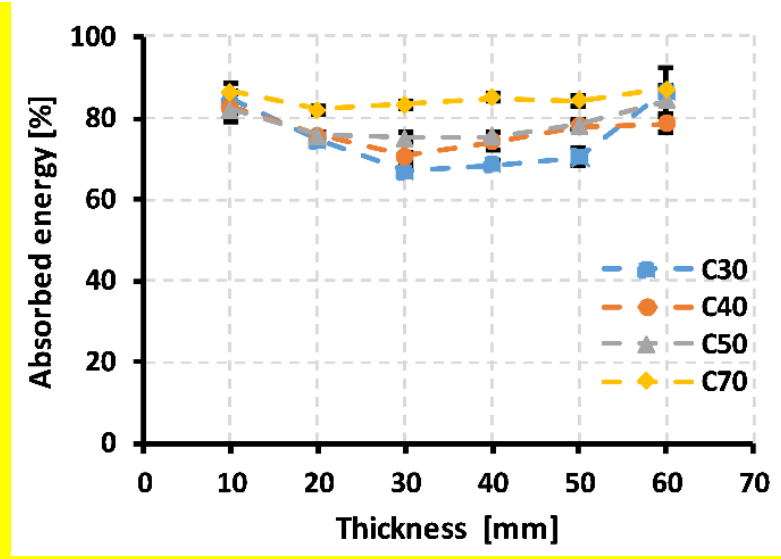

(a)

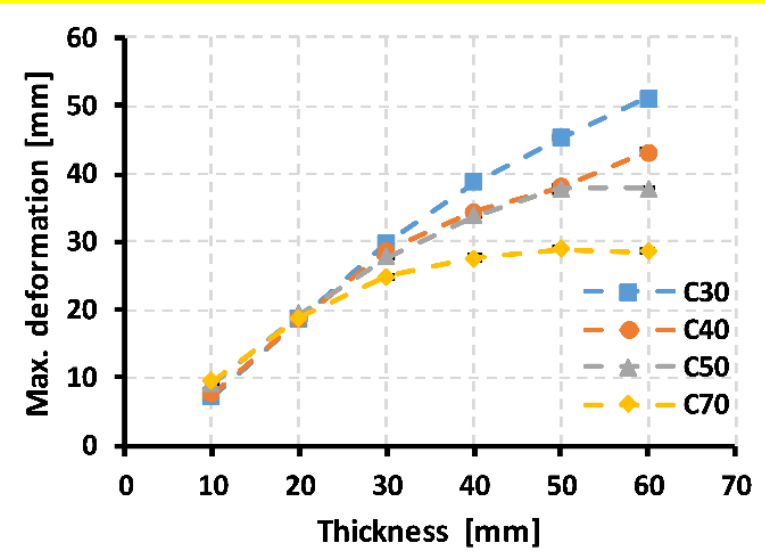

(c)

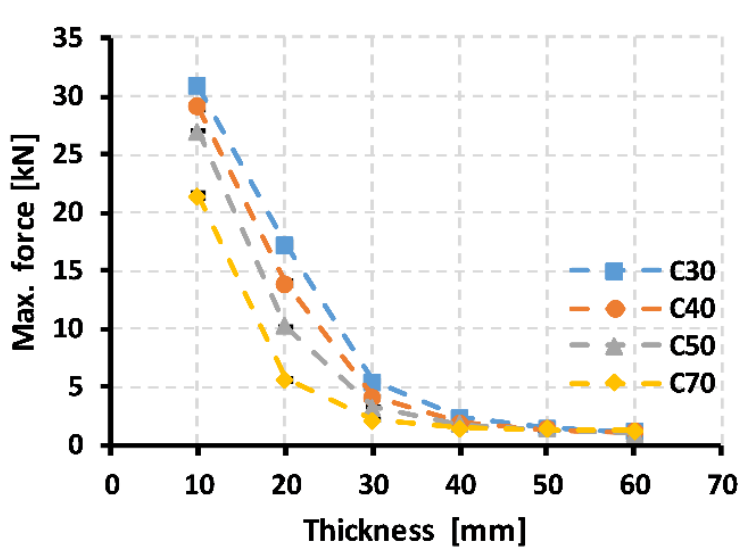

(b)

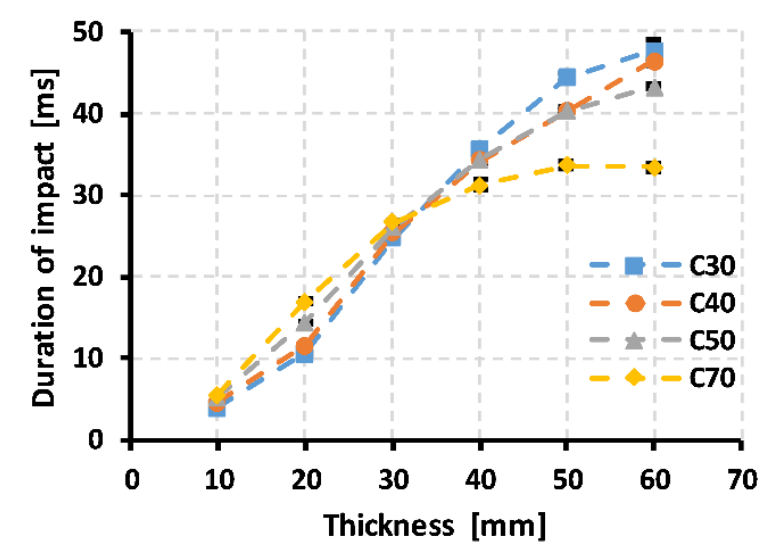

(d)

FIGURE 5 "Type A" falling weight impact test results as a function of thickness

(a) Absorbed energy (b) Maximum force, (c) Maximum deformation, (d) Duration of impact

The results show that the duration of impact varied in proportion to the thickness of the samples and the effect of density on the duration of impact was more significant from the thickness of $40 \mathrm{~mm}$ up, as higher density foams were less deformed compared to their thickness, leading to a reduction in the duration of impact.

It can be also stated that foam thickness significantly influences impact damping capability, since in the case of $10 \mathrm{~mm}$ thick foams, the maximum force ranged from $20 \mathrm{kN}$ to $30 \mathrm{kN}$ depending on foam density, while for $50 \mathrm{~mm}$ and $60 \mathrm{~mm}$ thick foams, this value decreased to $1.1-1.3 \mathrm{kN}$.

In contrast, the effect of foam density is not clear, since up to the thickness of $40 \mathrm{~mm}$, foams with higher density showed better impact damping properties, and the foams with the lowest density $\left(30 \mathrm{~kg} / \mathrm{m}^{3}\right)$ showed the highest maximum forces. This tendency did not occur for $50 \mathrm{~mm}$ thick and thicker foams; in this case, different density foams showed equal maximum forces. The fact that the maximum 
deformations up to the thickness of $30 \mathrm{~mm}$ were almost the same as the total thickness of the foam samples suggests that thinner foams are completely compacted (opposite cell walls touch each other) due to the impact (FIGURE 6).

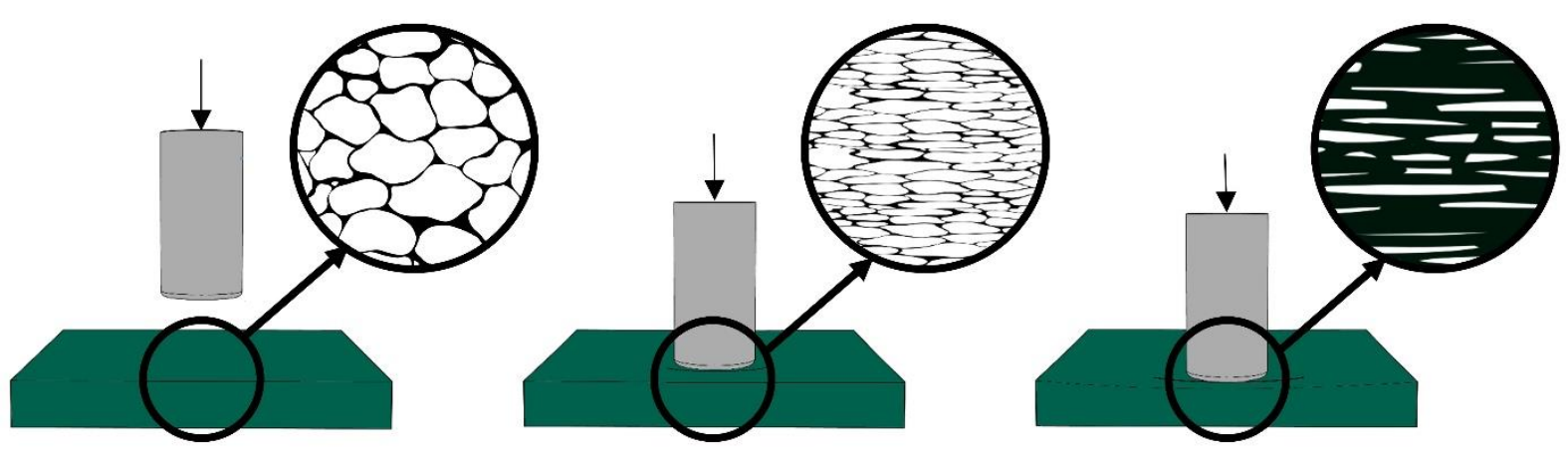

FIGURE 6 Compaction of the cell structure during the impact

These results correlate well with the trend detected in the compression tests, as the measured maximum deformation values are in the strain range of the densification zone of the compression stress-strain curves.

After the impact tests, we examined the changes in the cell structure of the fully compacted foams using SEM images. The image of sample C5010 (FIGURE 7) indicates that during the deformation of the cells, the cell walls were damaged in several places-there are 80-500 $\mu \mathrm{m}$ long lines and micro cracks (illustrated by red arrows). In the case of the other samples, the same type of damage was detected. This indicates that the complete compaction of the foam causes irreversible damage in the cell structure due to the excessive deformation.

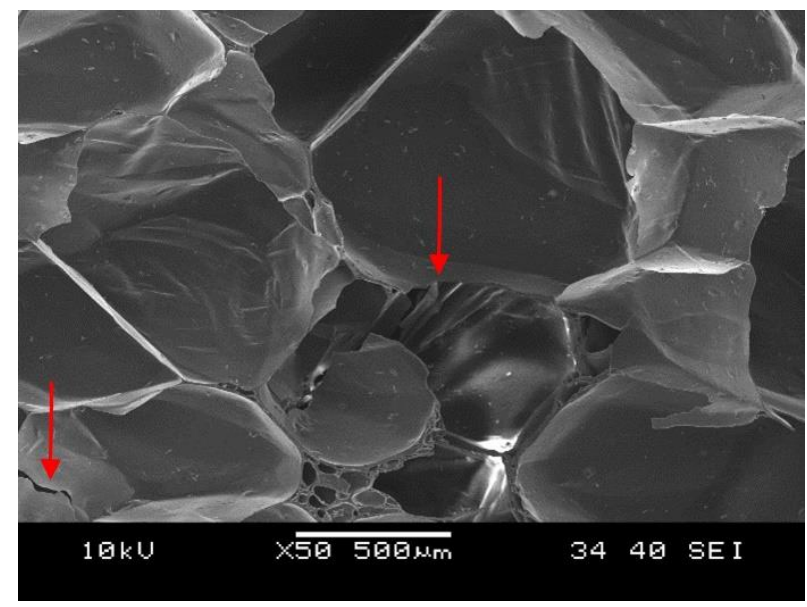

FIGURE 7 SEM image of sample C5010 after the falling weight impact test

The differences in the impact damping capability of the different density foams can be explained with their different cell structure and the different rate of deformation. Higher density foams have smaller cells and thicker cell walls resulting in a stiffer structure, which is more resistant to loads than lower density 
foams. As a result, during impacts, the $70 \mathrm{~kg} / \mathrm{m}^{3}$ foams decreased the speed of the striker more before the opposing cell walls met. This way, less energy was loaded on the compacted "solid" structure, which resulted in a lower maximum force. In the case of the $50 \mathrm{~mm}$ and $60 \mathrm{~mm}$ thick samples, the relative maximum deformation of the foams decreased as sample thickness increased. As a result, a solid structure was no longer formed and the difference between the impact damping of different density foams disappeared.

In contrast to maximum force, absorbed energy was not significantly influenced by foam thicknessfoams with different thicknesses showed similar energy absorption capability. Although the deformation of the thicker foams was greater, maximum force decreased with increasing thickness.

Up to the thickness of $50 \mathrm{~mm}$, absorbed energy increased with the density of the tested foams $-70 \mathrm{~kg} / \mathrm{m}^{3}$ density samples showed the highest, while $30 \mathrm{~kg} / \mathrm{m}^{3}$ density samples showed the lowest energy absorption. Similarly to the maximum force results, in the case of the thickest samples, the difference between the absorbed energy by the different density foams is almost zero, which can be explained by the force-deformation diagrams of the tests (FIGURE 8). 


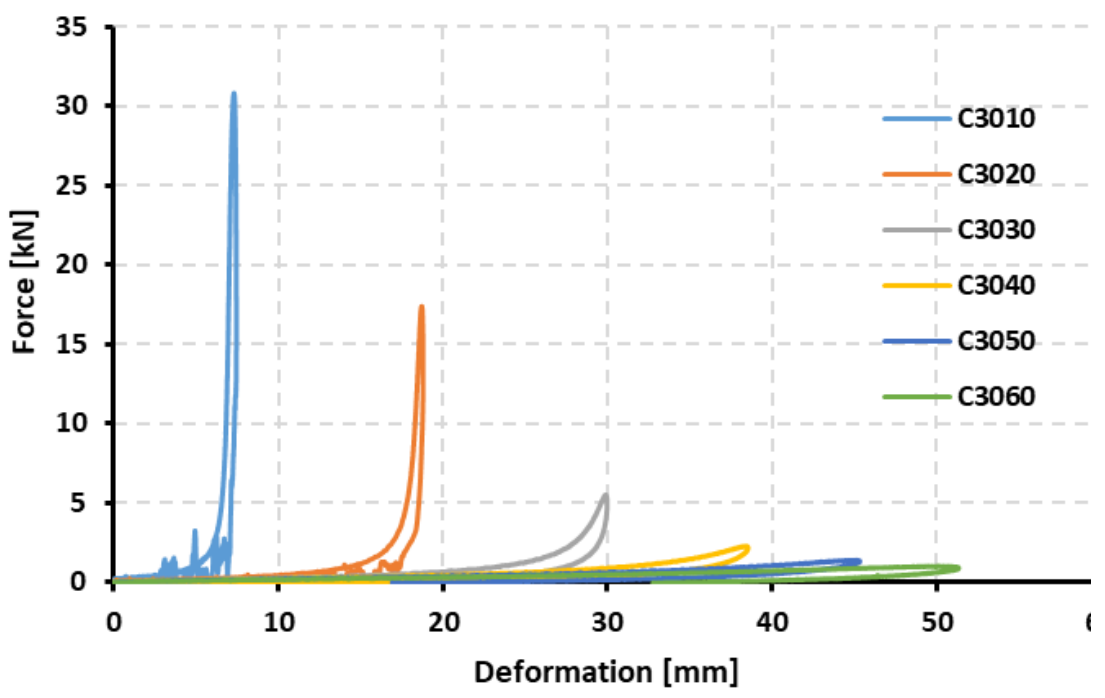

(a)

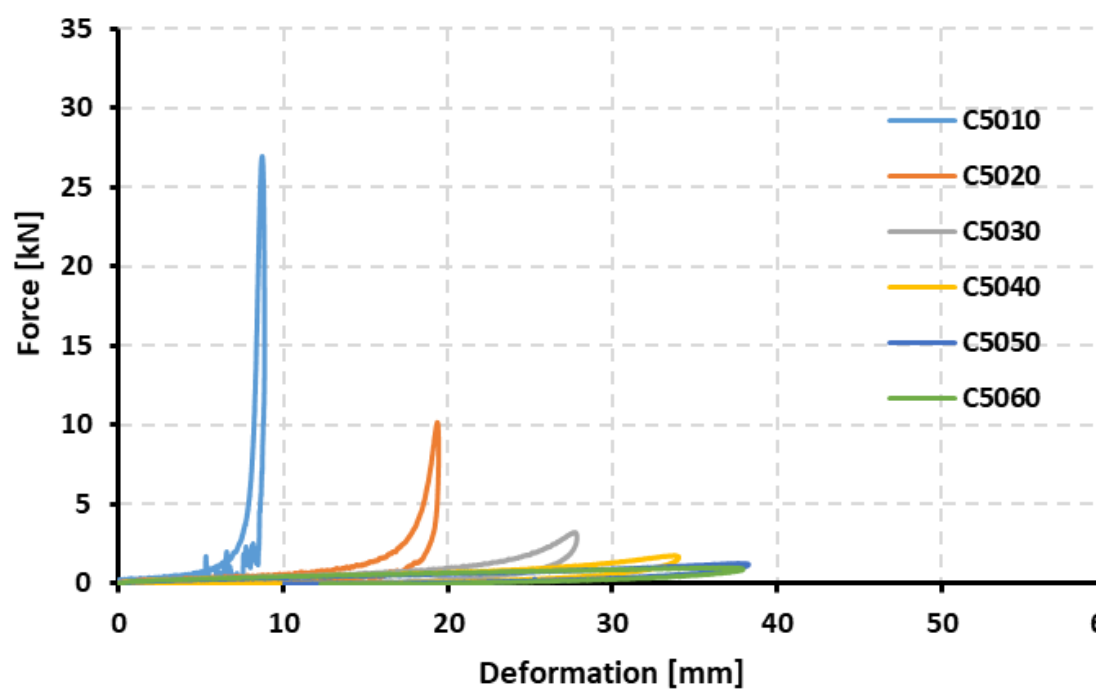

(c)

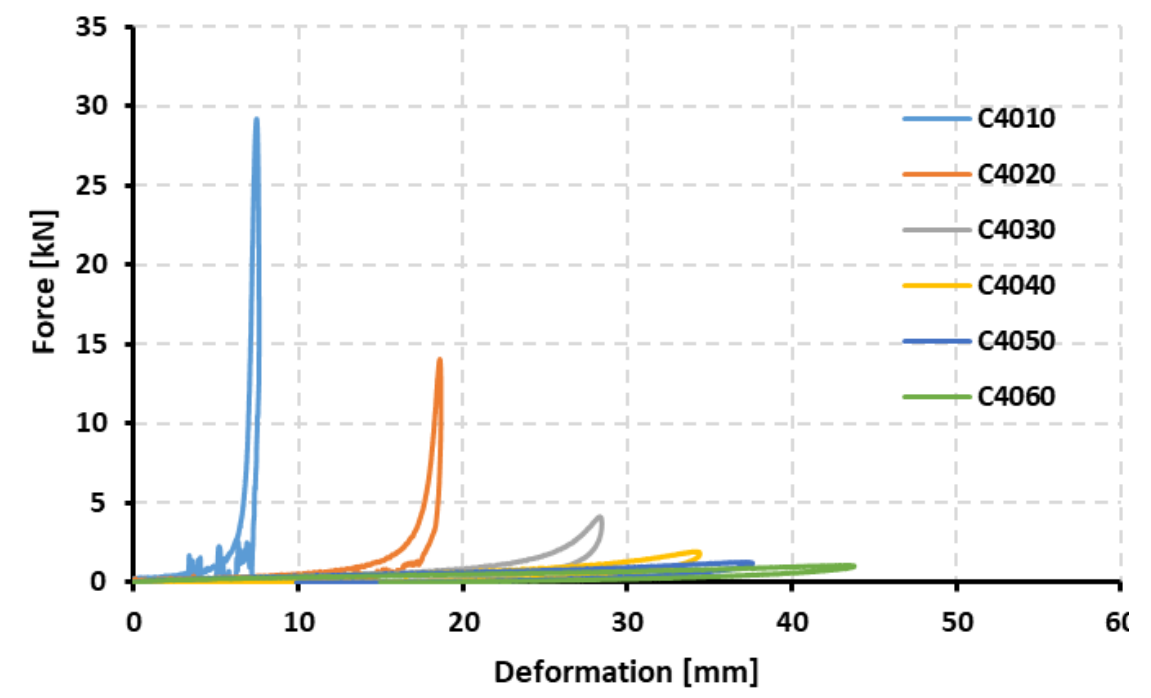

(b)

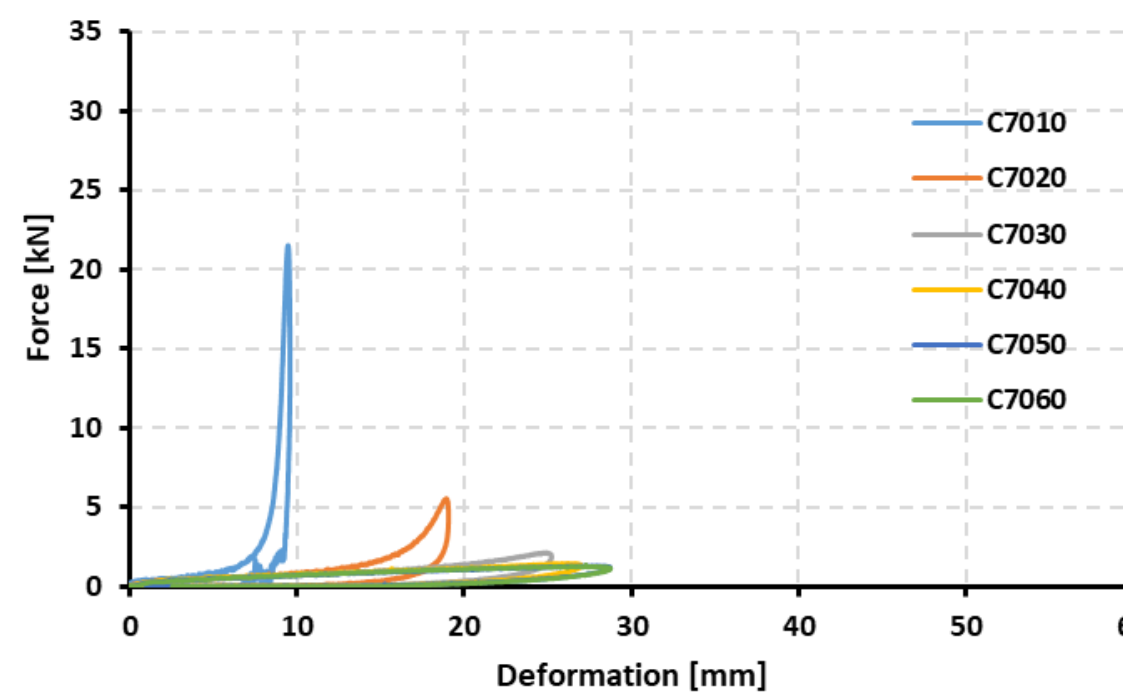

(d)

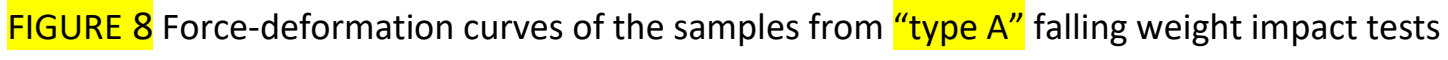

(a) $30 \mathrm{~kg} / \mathrm{m}^{3}$, (b) $40 \mathrm{~kg} / \mathrm{m}^{3}$, (c) $50 \mathrm{~kg} / \mathrm{m}^{3}$, (d) $70 \mathrm{~kg} / \mathrm{m}^{3}$ 
The diagrams confirm our hypothesis that the excessive deformation of the thinner foams led to the meeting of the opposite cell walls, and the samples approached the structural characteristics of a solid material, resulting in a large force increase in the second stage of the curves. In the first stage of the curves, the force exerted on the striker by the higher density foam (C7010) exceeds the force exerted by the lower density foam (C3010), so when the compacted "solid" structure is reached, the striker already has a lower speed, which reduces the maximum force. This trend is similar to the results of the compression tests, where higher density foams had a higher stress plateau.

Since the energy absorbed by the foams is equal to the area bounded by the curves, the thickness of the foam has no significant effect on energy absorption capability. The comparison of the curves of samples C7040, C7050, and C7060 also provides important information. Since the nature of the three curves is almost the same and there is no significant difference in the deformation and force values, we assume that a thickness of $40 \mathrm{~mm}$ is sufficient to maximize the impact damping and energy-absorbing capability of the $70 \mathrm{~kg} / \mathrm{m}^{3}$ density foam. This is because beyond a certain thickness, compaction due to the meeting of the opposite cell walls no longer occurs, therefore a further increase in foam thickness does not cause a significant improvement in impact damping properties. This thickness limit is a function of foam structure, average cell size, and cell wall thickness.

"Type B" falling weight impact tests were used to investigate the applicability of the foams as sports mats and analyze the effect of repetitive impacts on mechanical properties. The results were evaluated similarly to "type A" tests; the parameters were recorded with a uniaxial acceleration sensor built into the weight, and a laser distance measuring sensor.

FIGURE 9 summarizes the results of maximum force, absorbed energy, duration of impact, and maximum deformation. Since the results obtained with the $20 \mathrm{~mm}$ thick samples already approached the measuring limit of the accelerometer, we did not examine the $10 \mathrm{~mm}$ thick foams. 


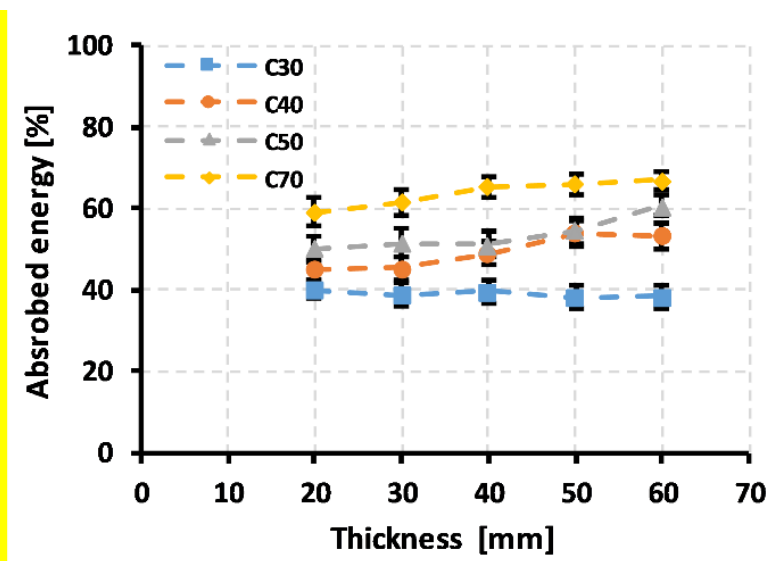

(a)

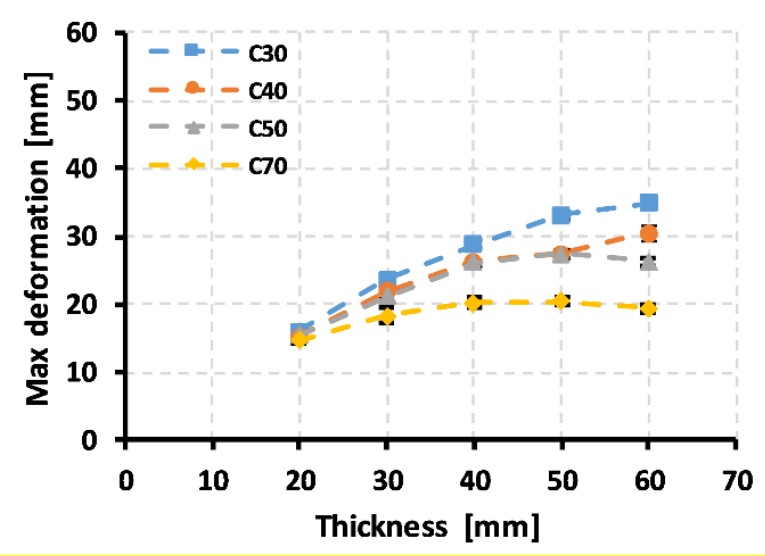

(c)

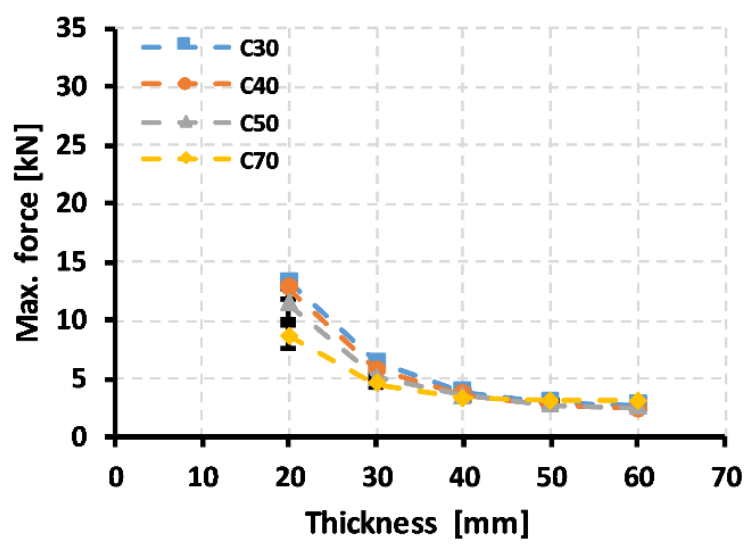

(b)

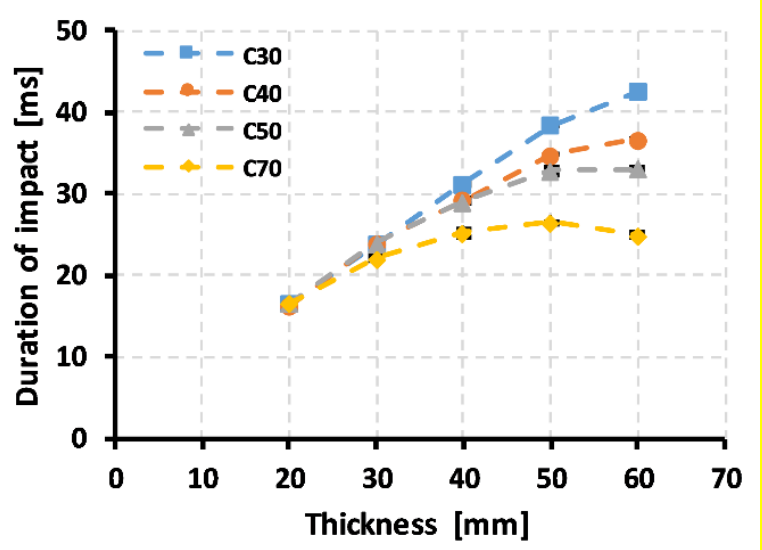

(d)

FIGURE 9 "Type B" falling weight impact measurement results in the function of thickness

(a) Absorbed energy, (b) Maximum force, (c) Maximum deformation, (d) Duration of impact

The test results showed the same tendency as the results of the "type A" impact tests. This suggests that impact damping capability is mainly influenced by foam thickness, while energy absorption is mostly influenced by foam density.

In "type B" tests, the specimens were less deformed than in "type A" tests. This can be explained with the lower impact energy per the contact surface during the impact. Although the impact energy used in the "type B" test exceeded the impact energy used in the "type A" tests, the load was distributed over a larger area due to the larger cylinder; more cells participated in the collision, resulting in less deformation.

Another difference is that absorbed energy in "type B" tests has greater standard deviation. This is caused by the test method, as the weight was dropped on the same sample several times in a row. As a result of the repetitive impacts, maximum force increased, and absorbed energy decreased. FIGURE 10 shows how maximum force changed during repeated impacts for the foams with $30 \mathrm{~kg} / \mathrm{m}^{3}$ density. The maximum force of foams with other densities showed a similar tendency. 


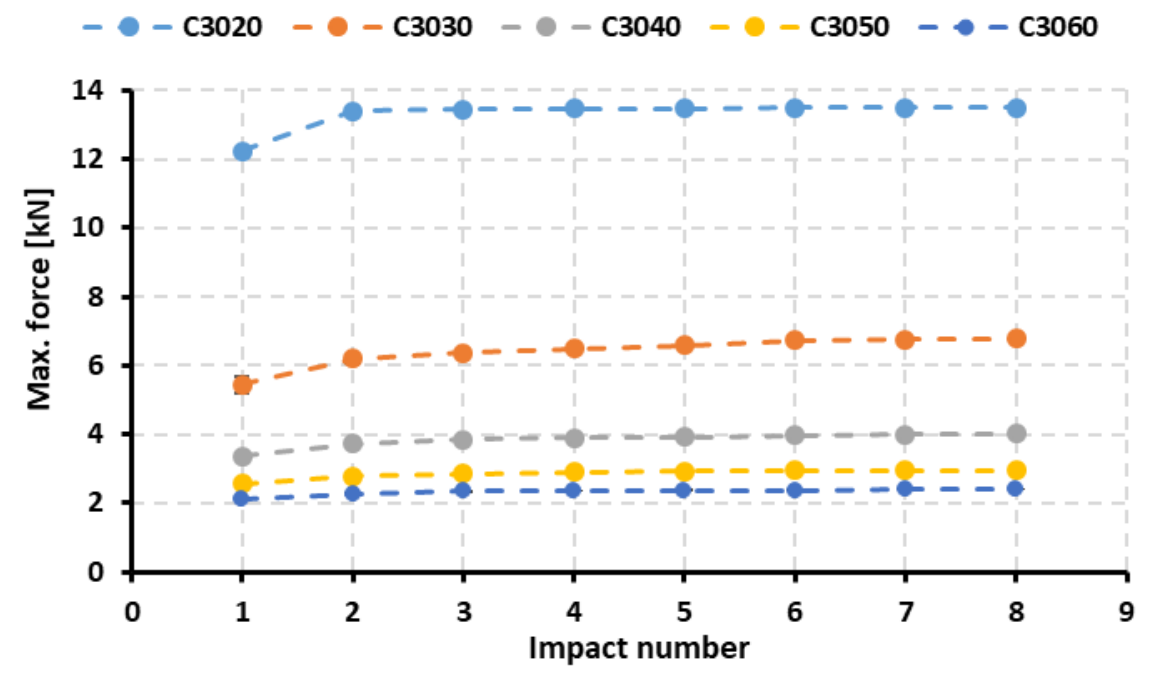

FIGURE 10 Maximum force results of the $30 \mathrm{~kg} / \mathrm{m}^{3}$ samples - the effect of repetitive impacts

The difference between the maximum force of the first and second impacts was always the largest; the following drops caused less deterioration in mechanical properties. However, the thicker the foam was, the less the first impact decreased impact damping capability. This can be explained with cell deformation (FIGURE 6). The greater deformation of the thinner foams led to the compaction of the cell structure, which caused permanent damage and micro cracks on the cell walls. The extent of damage likely depends on the degree of deformation, therefore this effect is less significant for thicker foams. In the case of the $20 \mathrm{~mm}$ thick foam, the difference between the first and second maximum forces exceeded $1 \mathrm{kN}$, while in the case of the thick C3060 foam, the difference did not even reach $200 \mathrm{~N}$.

Due to the phenomenon presented above, we have to determine the optimal thickness of a foam product to avoid compaction during operation, as this would impair the mechanical properties of the product permanently. Using the data obtained and knowing the maximum load specific to the application, the optimal thickness of a product with a given density can be determined to maximize the impact damping capability and minimize the amount of foam material required.

\section{CONCLUSIONS}

The aim of the research was to investigate the effect of the thickness of polymer foams on impact damping properties. Compression tests and two types of dynamic mechanical tests were performed on closed-cell cross-linked polyethylene foams with a density of $30-70 \mathrm{~kg} / \mathrm{m}^{3}$ and a thickness of $10-60 \mathrm{~mm}$. The cell structure of the foams was also analyzed by scanning electron microscopy.

Our results showed that foam thickness significantly influences the impact damping properties of the foams, while energy absorption capability is mainly related to the cellular structure of the foams and their density. We also showed that beyond a certain thickness, it is no longer possible to increase the impact damping capability of a foam of a given density, so an optimal thickness can be determined if the 
maximum load for the given application is known. This thickness limit is a function of foam structure, which can be described with average cell size and cell wall thickness.

Another important conclusion is that excessive compaction of the cells causes irreversible deformation in the microstructure of the material, therefore repetitive impacts impair the impact damping and energyabsorbing capability of the foams.

Our results can be utilized in many industries, including the sports and packaging industry, since in these industries, polymer foam products are graded by falling weight impact tests similar to the tests that we performed. In these fields, we can determine the optimal thickness of a polymer foam product with a given density, based on the maximum load expected in the application-to maximize impact damping capability and minimize the required amount of material.

\section{ACKNOWLEDGEMENTS}

This work was supported by the National Research, Development and Innovation Office, Hungary [K_19_132462], by the BME-Nanonotechnology FIKP grant [BME FIKP-NAT], by the 'UNKP-19-4 New National Excellence Program of the Ministry for Innovation and Technology', by the 'János Bolyai Research Scholarship of the Hungarian Academy of Sciences', and by United World Wrestling. The authors thank Polifoam Ltd. for providing the foam samples.

\section{REFERENCES AND NOTES}

1. Gibson, L. J.; Ashby, M. F. Cellular Solids: Structure and Properties; Cambridge University Press: Cambridge, 1997.

2. Szabó, V.; Dogossy, G. Period. Polytech. - Mech. Eng. 2020, 64, 81.

3. Jin, F.; Zhao, M.; Park, M.; Park, S. Polymers 2019, 11, 953.

4. Ferkl, P.; Pokorný, R.; Bobák, M.; Kosek, J. Chem. Eng. Sci. 2013, 97, 50.

5. Hung, T.-C.; Huang, J.-S.; Wang, Y.-W.; Lin, K.-Y. Constr. Build. Mater. 2014, 50, 328.

6. Heidari, A.; Fasihi, M. Express Polym. Lett. 2019, 13, 429.

7. Avalle, M.; Belingardi, G.; Montanini, R. Int. J. Impact Eng. 2001, 25, 455.

8. Mills, N. M. Polyolefin Foams; Rapra Technology Limited: Shawbury, 2003.

9. Zhang, Z.; Dai, X.; Zou, L.; Wen, S.; Sinha, T.; Li, H. Express Polym. Lett. 2019, 13, 948.

10. Brückner, K.; Odenwald, S.; Schwanitz, S.; Heidenfelder, J.; Milani, T. Procedia Eng. 2010, 2, 2789.

11. Mills, N. Polymer Foams Handbook: Engineering and Biomechanics Applications and Design Guide; Elsevier Science: Oxford, 2007.

12. Warnet, L.; Reed, P. E. In Mechanical Properties and Testing of Polymers: An A-Z Reference; Swallowe, G. M., Ed.; Springer Netherlands: Dordrecht, 1999. pp 66-70.

13. Velasco, J. I.; Martínez, A. B.; Arencón, D.; Rodríguez- Pérez, M. A.; De Saja, J. A. J. Mater. Sci. 1999, 34, 431.

14. Ruiz-Herrero, J. L.; Rodríguez-Pérez, M. A.; de Saja, J. A. Polym. Test. 2005, 24, 641.

15. Sek, M. A.; Minett, M.; Rouillard, V.; Bruscella, B. Packag. Technol. Sci. 2000, 13, 249.

16. EN 12503: Sports mats; 2013.

17. United World Wrestling, Regulations for the licensing of mats. https://unitedworldwrestling.org/sites/default/files/media/document/reglt homolog tapis a ne w.pdf (accessed April 29, 2020). 
18. EN 1621-2: Motorcyclists' protective clothing against mechanical impact - Part 2: Motorcyclists' back protectors - Requirements and test methods; 2014.

19. Flores-Johnson, E.; Li, Q. J. Cell. Plast. 2011, 47, 45.

20. Mills, N. J.; Gilchrist, A. Accid. Anal. Prev. 1991, 23, 153.

21. Lopez-Gonzalez, E.; Muñoz-Pascual, S.; Saiz-Arroyo, C.; Rodriguez-Perez, M. A. J. Appl. Polym. Sci. 2020, 137, 48468.

22. Mills, N.; Lyn, G. Cell. Polym. 2002, 21, 343.

23. Cui, L.; Kiernan, S.; Gilchrist, M. D. Mater. Sci. Eng. A 2009, 507, 215.

24. Higuchi, M.; Adachi, T.; Yokochi, Y.; Fujimoto, K. Mater. Sci. Forum 2012, 706-709, 729.

25. Shimazaki, Y.; Nozu, S.; Inoue, T. Polym. Test. 2016, 54, 98.

26. Juntunen, R. P.; Kumar, V.; Weller, J. E.; Bezubic, W. P. J. Vinyl Addit. Techn. 2000, 6, 93.

27. Kmetty, A.; Tomin, M.; Barany, T.; Czigany, T. Express Polym. Lett. 2020, 14, 503.

28. Marsavina, L.; Linul, E.; Voiconi, T.; Sadowski, T. Polym. Test. 2013, 32, 673.

29. Lyn, G.; Mills, N. J. Sports Eng. 2001, 4, 153.

30. Rodríguez-Pérez, M. Adv. Polym. Sci. 2005, 184, 55.

31. Chai, G. B.; Zhu, S. Proc. Inst. Mech. Eng. Pt. L J. Mater. Des. Appl. 2011, 225, 207.

32. Shim, E. In Joining Textiles: Principles and Applications; Jones, I.; Stylios, G. K., Eds.; Woodhead Publishing: Cambridge, 2013. pp 309-351.

33. Xu, X.; Park, C. B.; Xu, D.; Pop-lliev, R. Polym. Eng. Sci. 2003, 43, 1378.

34. Chul, B P. Foaming technology, SPE FOAMS 2017, Bayreuth, Germany, 2017.

35. Di Landro, L.; Sala, G.; Olivieri, D. Polym. Test. 2002, 21, 217.

\section{Graphical abstract}

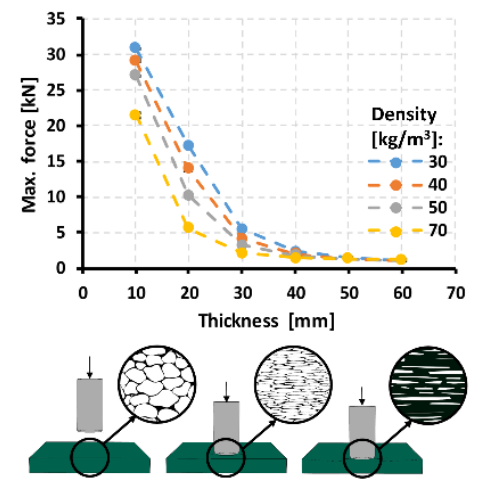

